\title{
Rapid photocatalytic degradation of methylene blue, tartrazine and brilliant green dyes by high-flux UV irradiation photolysis reactor
}

\author{
R. Rehman ${ }^{1 *}$, W. Uz-Zaman ${ }^{1}$, A. Abbas ${ }^{1}$, L. Mitu ${ }^{2}$ \\ ${ }^{1}$ Institute of Chemistry, University of the Punjab, Lahore-54590, Pakistan \\ ${ }^{2}$ Department of Chemistry, University of Pitesti, Pitesti-110040, Romania
}

Received October 24, 2017; Revised December 11, 2017

The aim of this work was to investigate the removal of dyes from wastewater by photocatalytic degradation using a modified assembly of photolysis reactor. It was more efficient and dye degradation occurred very fast. UV/Visible spectrophotometry was used to monitor the reaction. The degradation of dyes with different catalysts was compared and found to follow first-order kinetics. The optimal result for Methylene Blue was $\mathrm{t}_{(1 / 2)}=4 \mathrm{~min}, \mathrm{k}=0.4471 \mathrm{~min}^{-1}, \mathrm{R}^{2}=$ 0.9650 , for Tartrazine $-\mathrm{t}_{(1 / 2)}=1.2 \mathrm{~min}, \mathrm{k}=0.9723 \mathrm{~min}^{-1}, \mathrm{R}^{2}=0.9980$ and for Brilliant Green $-\mathrm{t}_{(1 / 2)}=0.8 \mathrm{~min}, \mathrm{k}=0.9716$ $\min ^{-1}, \mathrm{R}^{2}=0.9938$. So, it can be efficiently employed on a larger scale.

Keywords: Methylene Blue, Tartrazine, Brilliant Green, Photolysis, Degradation.

\section{INTRODUCTION}

Water contamination by coloring materials is a serious life threat. These coloring materials are known as dyes. They can originate from natural plant sources or synthetic ones. Synthetic dyes are usually better coloring materials, but their biodegradation is difficult. They can be classified into acidic (like Tartrazine or Congo Red) or basic (like: Methylene Blue, Brilliant Green) on the basis of $\mathrm{pH}$, or on the basis of functional groups like sulphonic, azo, naphtholic dyes, etc. They are commonly used in textile, leather, paper, paint and pharmaceutical industries for coloring various materials [1-8]. Their discharge in waste streams leads to depletion in light penetration into deeper layers of water. This leads to death of aquatic plant and animal species, disturbing food chain and ecosystem in a brutal way. So, their continuous removal from waste streams in an economical and efficient way is very crucial for saving life on this planet [9-16].

There are various physico-chemical and biological methods for removing these dyes. The adsorption on synthetic or agricultural waste derived activated material is the most common method of removal of dyes [16-21]. Dyes can be degraded biologically, chemically or using photolysis [22-25]. Natural methods of degradation are microbial and photolytic [26-32].

Some weaknesses of these practices are: long time is required and resulting byproducts are more harmful for the ecosystem. For example: using $\mathrm{ZnO}$ and UV light, $64.90 \%$ degradation of Methylene Blue, Methyl Orange and Reactive Orange 16 occurred in 2 hours. Using Caln $\mathrm{O}_{4}$, degradation of $47.8 \mu \mathrm{mol} / \mathrm{L}$ of Methylene Blue was achieved in neutral medium within 2 hours. Design of a simple reactor formerly commonly used for photolysis is shown in Fig. 1 [16-18].

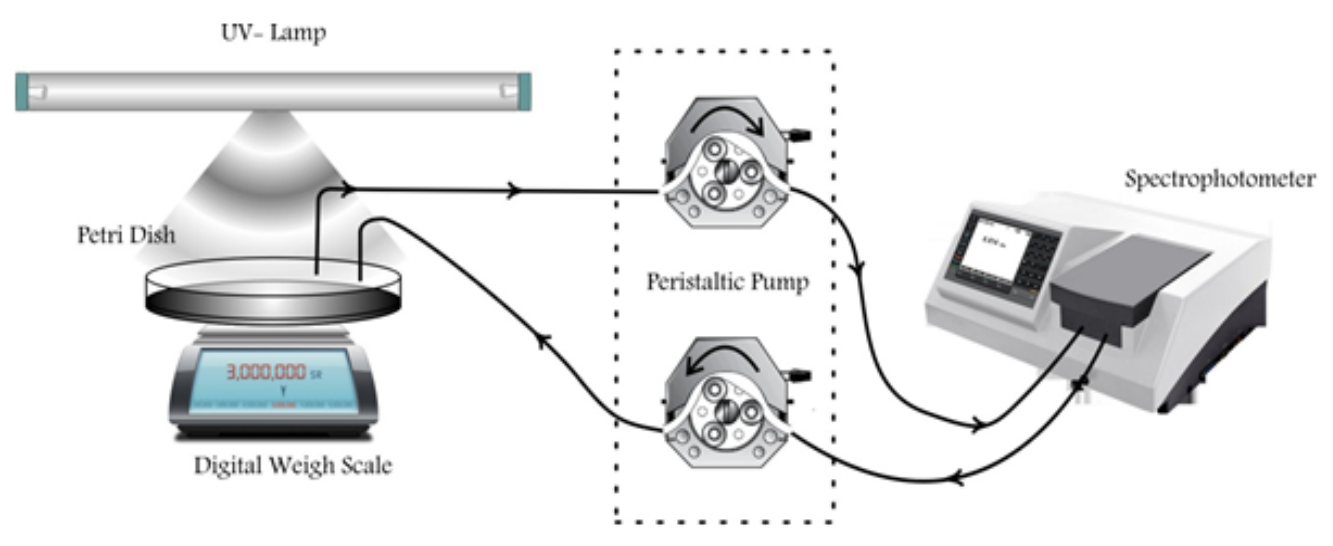

Fig. 1. The UV degradation setup for dyes.

\footnotetext{
* To whom all correspondence should be sent: 


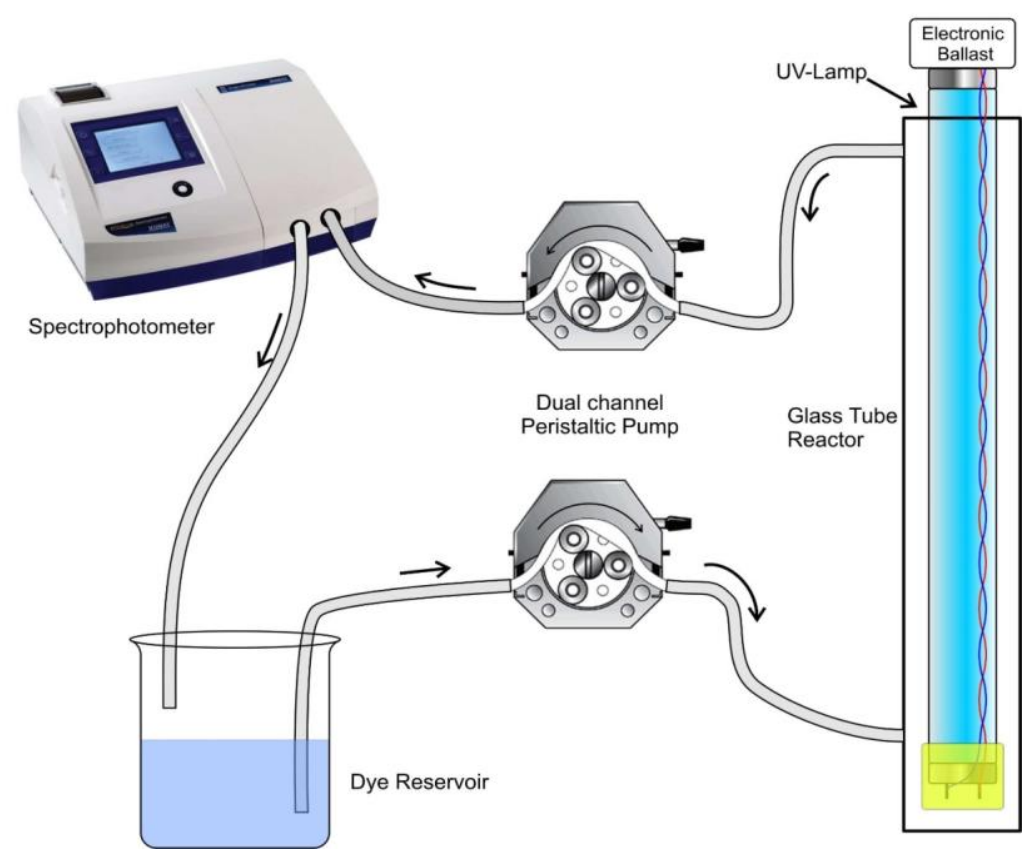

Fig. 2. Systematic diagram of the newly designed photolysis reactor.

The problems faced in this setup are:

(i) Distance between light source and dye solution is large, resulting in wastage of UV light intensity along with decrease in efficiency of process.

(ii) UV light converts $\mathrm{O}_{2}$ present in ambient air into $\mathrm{O}_{3}$ (ozone).

(iii) Ozone production lowers the efficiency of the process and moreover, it is toxic for the environment.

(iv) Ozone delays the photodegradation of dye.

So, there is need to develop an efficient assembly for degradation of dyes. In this work, that design was presented and applied for degradation of Methylene Blue, Tartrazine and Brilliant Green dyes.

\section{EXPERIMENTAL}

The assembly shown in Fig. 2 was used in this work for addressing the above mentioned issues in an effective and economical way using indigenous sources.

It consists of UV lamp put inside a hollow cylindrical glass rod with two openings, one on the upper side and a second one on the lower side. They are joined through peristaltic pumps to dye solution container and UV/Vis spectrometer.

Since the UV light source and dye solution are in close contact, maximum light is used for photodegradation of the dye in a short interval of time. Along with this, it has the following advantages:

(i) No light intensity and energy is wasted. (ii) As there is no air in-between UV light and dye solution, no ozone production takes place.

(iii) Less time is required for photodegradation; and last, but not least, this process is in continuous mode which is superior to batch process for removal of dyes for adopting on industrial scale.

\section{Methodology for photocatalytic degradation}

Chemicals: Methylene Blue, Brilliant Green, Tartrazine, $\mathrm{H}_{2} \mathrm{O}_{2}, \mathrm{TiO}_{2}$, all obtained from Merck (Germany).

Equipment used: Tubular UV lamp (15 Watts, length $43 \mathrm{~cm}, \phi 27 \mathrm{~mm}$ ), Electrical balance, $\mathrm{pH}$ meter, UV/VIS spectrophotometer, quartz flow cell $(10 \mathrm{~mm})$, dual channel peristaltic pump, magnetic stirrer.

Preparation of stock solutions: $1 \mathrm{M}$ stock solution of each dye was used. Further dilutions required for each dye were accordingly prepared.

Setup used for photodegradation investigations: For this, a UV lamp, dual channel peristaltic pump with $150 \mathrm{~mL} / \mathrm{min}$ flow rate and UV-Vis spectrometer were used. Spectrometer was attached to PC for data monitoring. Dye solution was loaded in a beaker with magnetic stirrer and placed on a hot plate. The peristaltic pump takes this solution to the glass tube reactor from the bottom side, where it is exposed to UV radiation. Then the dye solution goes to the spectrometer flow cell from the upper side through the peristaltic pump. After this, it is mixed again with the initial solution container. As degradation proceeded, the concentration of dye solution was continuously monitored at $655 \mathrm{~nm}$ for Methylene Blue, $425 \mathrm{~nm}$ for Tartrazine and $625 \mathrm{~nm}$ 
R. Rehman et al.: Rapid photocatalytic degradation of Methylene Blue, Tartrazine and Brilliant Green dyes by ... for Brilliant Green dye, through a PC based data logging system [13-17].

\section{(i) Degradation of dyes without catalyst}

Dye solutions $(0.06 \mathrm{mM}$ of Methylene Blue, $0.018 \mathrm{mM}$ of Tartrazine and $0.08 \mathrm{mM}$ of Brilliant Green) were run through this assembly one by one and came in contact with the UV light and the absorption of the solution was noted after regular time intervals.

\section{(ii) Degradation of dyes with catalyst $\mathrm{TiO}_{2}$}

Solutions of Methylene Blue (0.03 mM), Tartrazine $(0.036 \mathrm{mM})$ and Brilliant Green $(0.08$ $\mathrm{mM}$ ) were prepared. To each $5 \mathrm{mg}$ of $\mathrm{TiO}_{2}$ catalyst was added. Then the solution was passed through the assembly and the light absorption was registered.

\section{(iii) Degradation of dyes with $\mathrm{H}_{2} \mathrm{O}_{2}$}

Solutions of Methylene Blue (0.03 mM), Tartrazine $(0.036 \mathrm{mM})$ and Brilliant Green $(0.08$ $\mathrm{mM}$ ) were prepared. Then $0.5 \mathrm{~mL}$ of $\mathrm{H}_{2} \mathrm{O}_{2}$ was added to each. The solutions were placed on the stirrer and passed through the reactor. Then the light absorption was registered.

(iv) Degradation of dyes with $\mathrm{TiO}_{2}$ and $\mathrm{H}_{2} \mathrm{O}_{2}$

Solutions of Methylene Blue $(0.03 \mathrm{mM})$, Tartrazine $(0.036 \mathrm{mM})$ and Brilliant Green $(0.08$ $\mathrm{mM}$ ) were prepared and $5 \mathrm{mg}$ of $\mathrm{TiO}_{2}$ and $0.5 \mathrm{~mL}$ of $\mathrm{H}_{2} \mathrm{O}_{2}$ were added in all of them. Then they were passed through the reactor and degradation of dyes was monitored.

\section{RESULTS AND DISCUSSION}

The degradation of dyes was performed using UV light and catalysts. The absorption of dye solutions was monitored and graphically represented below. It was shown that degradation of dyes followed first-order kinetics (eq. 1):

$$
\ln \left(\mathrm{A}_{0} / \mathrm{A}_{\mathrm{t}}\right)=\mathrm{kt}
$$

Here $A_{0}$ is the initial dye solution absorbance and $A_{t}$ is the absorbance after time $t, k$ is rate constant [18-27]. All experiments were performed in triplicate and average values were used for graphical representation and statistical validation using paired t-test.

\section{Case 1: Photolytic degradation of Methylene Blue}

(a) Without catalyst: The results are shown in Fig. 3. The statistical analysis indicated that $1^{\text {st }}$ order kinetic model was followed. Complete removal of dye occurred within $110 \mathrm{~min}$. $\mathrm{t}(1 / 2)=$ 110 min, $\mathrm{K}=0.006302 \mathrm{~min}^{-1}, \mathrm{R}^{2}=0.996091$.

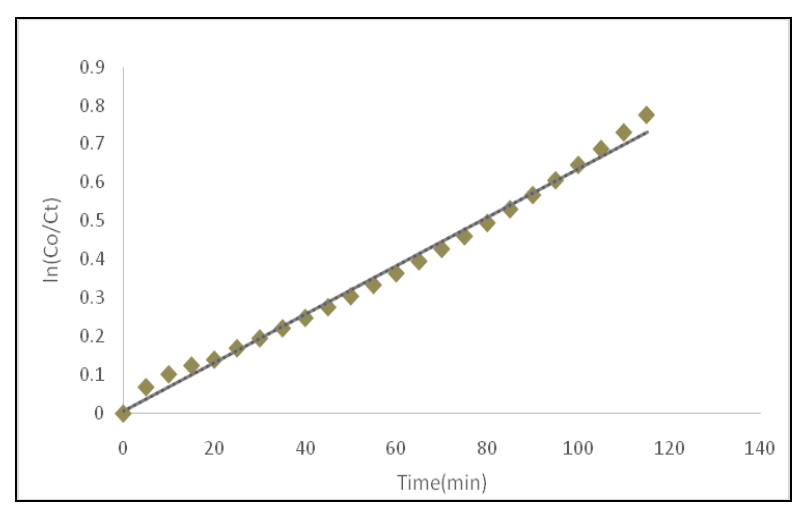

Fig. 3. Photolysis kinetics of Methylene Blue without catalyst.

(b) With catalysts $\mathrm{TiO}_{2}, \mathrm{H}_{2} \mathrm{O}_{2}$ applied separately and simultaneously: The results are graphically presented in Fig. 4. Statistical analysis indicated that $1^{\text {st }}$ order kinetic model was followed. Statistical results are as follows:

with $\mathrm{TiO}_{2}: \mathrm{t}_{(1 / 2)}=29 \min , \mathrm{K}=0.022984 \mathrm{~min}^{-1}, \mathrm{R}^{2}=$ 0.99560

with $\mathrm{H}_{2} \mathrm{O}_{2}: \mathrm{t}_{(1 / 2)}=4$ min, $\mathrm{K}=0.447125 \mathrm{~min}^{-1}, \mathrm{R}^{2}=$ 0.965032

with $\mathrm{TiO}_{2}+\mathrm{H}_{2} \mathrm{O}_{2}: \mathrm{t}_{(1 / 2)}=2.5 \mathrm{~min}, \mathrm{~K}=0.162375 \mathrm{~min}^{-}$ ${ }^{1}, \mathrm{R}^{2}=0.954916$.

Complete removal of dye occurred within 2.5 min using both catalysts at the same time. So, it can be effectively employed on larger scale Methylene Blue removal in an economical way like adsorptive removal of methylene blue or using other catalytic methods for removal of dyes [28-33].

\section{Case 2. Photolytic degradation of Tartrazine}

(a) Without catalyst: The results are shown in Fig. 5. The statistical analysis revealed that it followed the same $1^{\text {st }}$ order kinetic model with $\mathrm{t}_{(1 / 2)}$ $=2.75 \mathrm{~min}, \mathrm{~K}=0.498606 \mathrm{~min}^{-1}, \mathrm{R}^{2}=0.982249$.

(b) With catalysts $\mathrm{TiO}_{2}, \mathrm{H}_{2} \mathrm{O}_{2}$ applied separately and simultaneously: The results are presented in Fig. 6. Their statistical validation indicated that $1^{\text {st }}$ order kinetic model was followed in all cases:

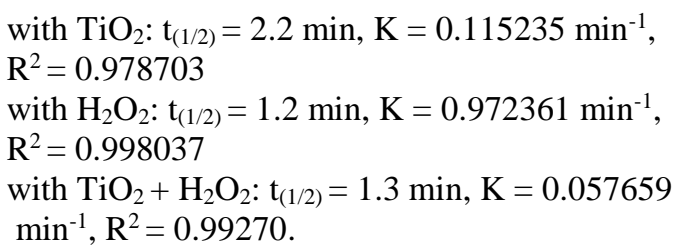




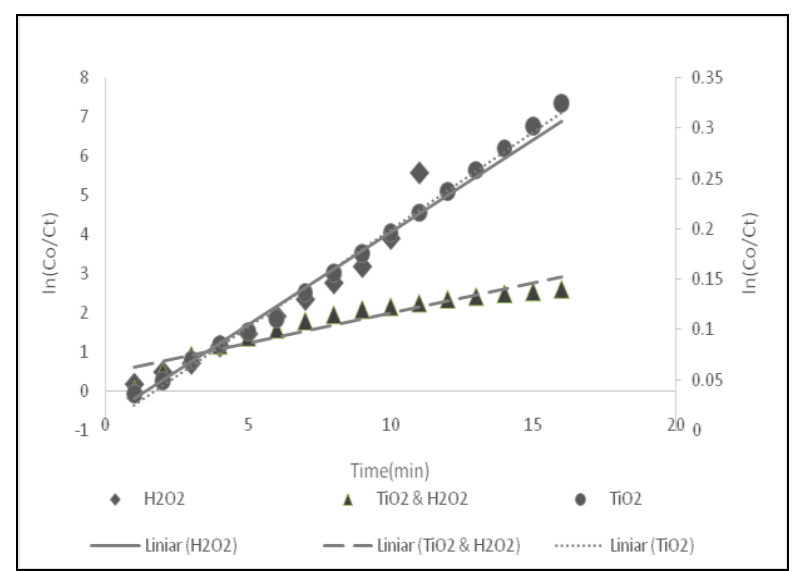

Fig. 4. Photolysis kinetics of Methylene Blue with catalysts $\mathrm{TiO}_{2}, \mathrm{H}_{2} \mathrm{O}_{2}$ used separately and simultaneously.

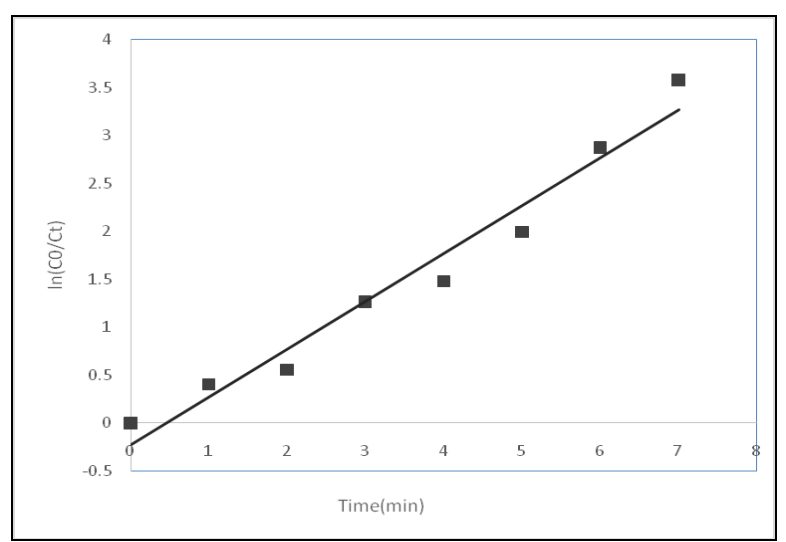

Fig. 5. Photolysis kinetics of Tartrazine without catalyst.

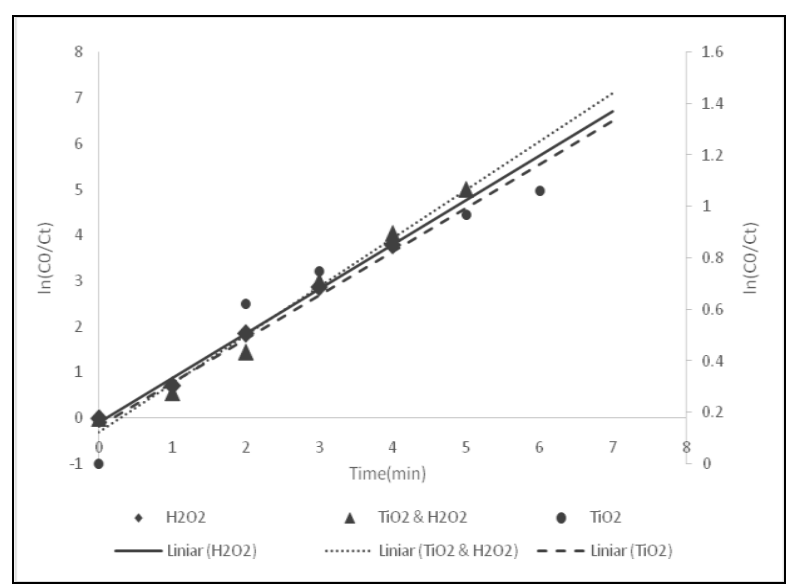

Fig. 6. Photolysis kinetics of Tartrazine with catalysts $\mathrm{TiO}_{2}, \mathrm{H}_{2} \mathrm{O}_{2}$ used separately and simultaneously.

Statistical correlation indicated that the catalysts can be effectively employed on a larger scale for removal of Tartrazine dye like any other methodology of removal of dyes [28-33].

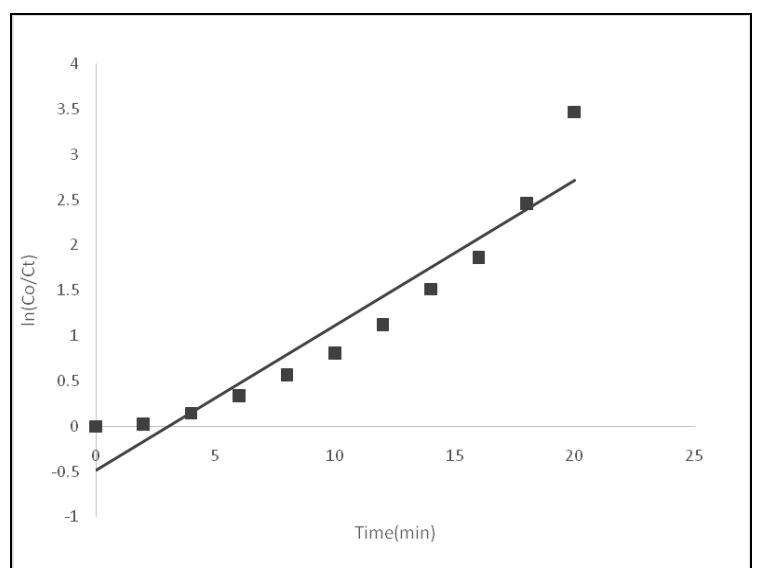

Fig. 7. Photolysis kinetics of Brilliant Green without catalyst.

Case 3: Photolytic degradation of Brilliant Green

(a) Without catalyst: The degradation is graphically represented in Fig. 7. Its statistical modeling indicated that degradation of Brilliant green followed a $1^{\text {st }}$ order kinetic model and maximum dye removal occurred within $9.1 \mathrm{~min}$. $\mathrm{t}_{(1 / 2)}=9.1 \mathrm{~min}, \mathrm{~K}=0.159895 \mathrm{~min}^{-1}, \mathrm{R}^{2}=0.950303$.

(b) With catalysts $\mathrm{TiO}_{2}, \mathrm{H}_{2} \mathrm{O}_{2}$ used separately and simultaneously: Fig. 8 shows the degradation results for Brilliant Green with catalysts $\mathrm{TiO}_{2}$ and $\mathrm{H}_{2} \mathrm{O}_{2}$ used separately and simultaneously. Their statistical modeling is as follows:

$$
\begin{aligned}
& \text { with } \mathrm{TiO}_{2}: \mathrm{t}_{(1 / 2)}=5.2 \mathrm{~min}, \mathrm{~K}=0.364276 \mathrm{~min}^{-1} \text {, } \\
& \mathrm{R}^{2}=0.861151 \\
& \text { with } \mathrm{H}_{2} \mathrm{O}_{2}: \mathrm{t}_{(1 / 2)}=0.8 \mathrm{~min}, \mathrm{~K}=0.971629 \mathrm{~min}^{-1} \text {, } \\
& \mathrm{R}^{2}=0.993809 \\
& \text { with } \mathrm{TiO}_{2} \text { and } \mathrm{H}_{2} \mathrm{O}_{2}: \mathrm{t}_{(1 / 2)}=0.9 \mathrm{~min}, \\
& \mathrm{~K}=0.952320 \mathrm{~min}^{-1}, \mathrm{R}^{2}=0.98018 \text {. }
\end{aligned}
$$

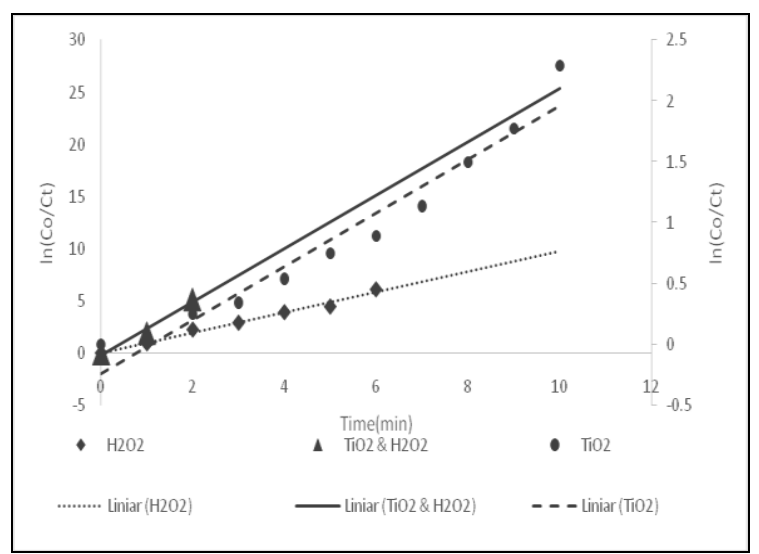

Fig. 8. Photolysis kinetics of Brilliant Green with catalysts $\mathrm{TiO}_{2}, \mathrm{H}_{2} \mathrm{O}_{2}$ used separately and simultaneously.

The same trend as for Tartrazine is shown: complete dye removal occurred within $0.8 \mathrm{~min}$ using $\mathrm{H}_{2} \mathrm{O}_{2}$ only. So, $\mathrm{H}_{2} \mathrm{O}_{2}$ can be efficiently employed for adsorptive removal of Methylene Blue or using other catalytic methods for removal of dyes [26-32]. 


\section{R. Rehman et al.: Rapid photocatalytic degradation of Methylene Blue, Tartrazine and Brilliant Green dyes by ...}

\section{CONCLUSIONS}

The photodegradation of dyes was performed under UV light by using a modified method. Kinetic studies indicated that photolytic degradation of dyes followed a first-order kinetic model. The rate of degradation of dyes was very high in presence of catalysts such as $\mathrm{TiO}_{2}$ and $\mathrm{H}_{2} \mathrm{O}_{2}$. The optimal result for Methylene Blue was $\mathrm{t}_{(1 / 2)}=4 \mathrm{~min}, \mathrm{k}=0.4471 \mathrm{~min}^{-1}, \mathrm{R}^{2}=0.9650$, for Tartrazine was $\mathrm{t}_{(1 / 2)}=1.2 \mathrm{~min}, \mathrm{k}=0.9723 \mathrm{~min}^{-1}, \mathrm{R}^{2}$ $=0.9980$ and for Brilliant Green was $\mathrm{t}_{(1 / 2)}=0.8 \mathrm{~min}$, $\mathrm{k}=0.9716 \mathrm{~min}^{-1}, \mathrm{R}^{2}=0.9938$. This developed methodology is economical, safe to use, developed from local resources and proved to be very efficient for degradation of dyes and other contaminants in an ecofriendly way.

\section{REFERENCES}

1. D. Pathania, G. Sharma, A. Kumar, M. Naushad, S. Kalia, A. Sharma, Z. A.ALOthman, Toxicol. Env. Chem., 97, 526 (2015).

2. M. Rauf, M. Meetani, S. Hisaindee, Desalination, 276, 13 (2011).

3. A. Kumar, G. Sharma, M. Naushad, P. Singh, S. Kalia, J. Industr. Eng. Chem. Res., 53, 15549 (2014).

4. D. Pathania, D. Gupta, H. Ala'a, G. Sharma, A. Kumar, M. Naushad, T. Ahamad, S. M. Alshehri, J. Photochem. Photobiol. A: Chem., 329, 61 (2016).

5. U. Akpan, B. Hameed, J. Hazard. Mat., 170, 520 (2009).

6. R. Rehman, J. Anwar, T. Mahmud, J. Chem. Soc. Pak., 34, 460 (2012).

7. W. Subramanian, T.Y. Wu, Water, Air \& Soil Poll., 225, 1 (2014).

8. H. Javadian, M. T. Angaji, M. Naushad, J. Industr. Eng. Chem. Res., 20, 3890 (2014).

9. N. Shanmugam, T. Sathya, G. Viruthagiri, C. Kalyanasundaram, R. Gobi, S. Ragupathy, Appl. Surf. Sci., 360, 283 (2016).

10. A. Houas, H. Lachheb, M. Ksibi, E. Elaloui, C. Guillard, J.M. Herrmann, Appl. Catal. B: Env., 31, 145 (2001).

11. I.K. Konstantinou, T.A. Albanis, Appl..Catal. B: Env., 49, 1 (2004).

12. R.J. Tayade, T.S. Natarajan, H.C. Bajaj, Industr. Eng. Chem. Res., 48, 10262 (2009).

13. J. Tang, Z. Zou, J. Yin, J. Ye, Chem. Phys. Lett., 382, 175 (2003).
14. S. Lakshmi, R. Renganathan, S. Fujita, J. Photochem. Photobiol. A: Chem., 88, 163 (1995).

15. P. Oancea, V. Meltzer, Chem. Papers, 68, 105 (2014).

16. F. Parolin, U.M. Nascimento, E.B. Azevedo, Env. Technol., 34, 1247 (2013).

17. V.K. Gupta, R. Jain, A. Nayak, S. Agarwal, M. Shrivastava, Mat. Sci. Eng., Part C, 31, 1062 (2011).

18. M.J.N. Gotostos, C.C. Su, M.D.G. De Luna, M.C. Lu, J. Env. Sci. Health, Part A, 49, 892 (2014).

19. R. Khosravi, A. Zarei, M. Heidari, A. Ahmadfazeli, M. Vosughi, M. Fazlzadeh, Korean J. Chem. Eng., 35, 1000 (2018).

20. 20. H. Golestanifar, A. Asadi, A. Alinezhad, B. Haybati, M. Vosoughi, Deswater, 57, 5480 (2016).

21. Y. Rashtbari, S. Hazrati, S. Afshin, M. Fazlzadeh, M. Vosoughi, Data Brief, 20, 1434 (2018).

22. G. Sharma, M. Naushad, D. Pathania, A. Mittal, G. El-Desoky, Deswater, 54, 3114 (2015).

23. G. Sharma, M. Naushad, A. Kumar, S. Rana, S. Sharma, A. Bhatnagar, F. J. Stadler, A. A. Ghfar, M. R. Khan, Process Safety Env. Protect., 109, 301 (2017).

24. M. Ahemad, M. Kibret, Biochem. Mol. Biol., 1, 19 (2013).

25. A. A. Alqadami, M. Naushad, M. A. Abdalla, M. R. Khan, Z. A. Alothman, J. Chem. Eng. Data, 61, 3806 (2016).

26. A. Kumar, G. Sharma, M. Naushad, A. Kumar, S. Kalia, C. Guo, G. T. Mola, J. Photochem. Photobiol. A: Chem., 337, 118 (2017).

27. M. Rauf, S.S. Ashraf, Chem. Eng. J., 151, 10 (2009).

28. H. Lachheb, E. Puzenat, A. Houas, M. Ksibi, E. Elaloui, C. Guillard, J.M. Herrmann, Appl. Catal. B: Env., 39, 75 (2002).

29. M. Naushad, T. Ahamad, B. M. Al-Maswari, A. A. Alqadami, S. M. Alshehri, Chemical Engineering Journal, 330, 1351 (2017).

30. D. Pathania, R. Katwal, G. Sharma, M. Naushad, M. R. Khan, H. Ala'a, Int. J. Biol. Macromol., 87, 366 (2016).

31. A. B. Albadarin, M. N. Collins, M. Naushad, S. Shirazian, G. Walker, C. Mangwandi, Chem. Eng. J., 307, 264 (2017).

32. M. Naushad, T. Ahamad, G. Sharma, H. Ala'a, A. B. Albadarin, M. M. Alam, Z. A. ALOthman, S. M. Alshehri, A. A. Ghfar, Chem. Eng. J., 300, 306 (2016).

33. E. Daneshvar, A. Vazirzadeh, A. Niazi, M. Kousha, M. Naushad, A. Bhatnagar, J. Cleaner Prod., 152, 443 (2017). 